\title{
DNAオリガそを使った1分子解析 \\ 遠藤政幸 ${ }^{1,3}$, 杉山 弘 ${ }^{1,2,3}$ \\ '京都大学物質-細胞統合システム拠点(WPI-iCeMS) \\ 2京都大学大学院理学研究科 \\ ${ }^{3}$ JST CREST
}

The dynamic behaviors of the enzymes and DNA structural changes were visualized using the designed DNA origami structures and high-speed AFM. The movement and the reactions of DNA methyltransferase, DNA repair enzymes, and RNA polymerase were observed by introducing the substrate double-stranded DNAs (dsDNA) to the DNA nanostructures. For the formation and disruption of G-quadruplex and double-stranded DNA, the two dsDNA incorporated in the DNA frame can amplify the small structural change to the global structural change, which enable the visualization of the reactions. The stepwise strand migration of a DNA nanomachine was visualized and analyzed on the DNA track constructed on the DNA origami surface.

DNA origami / high-speed atomic force microscopy / single-molecule observation / enzyme reactions / DNA structural change / DNA nanomachine

1.

はじめに

DNA は塩基配列特異的な分子集合や明確で周期的 な構造などを併せ持つ優れた生体超分子である。この DNA に特徵的な分子集合のプログラム性と構造の規 則性を使って様々なナノスケールの構造体を作製する 技術の開発が行われてきた ${ }^{1)}$. 特に, 近年発表された DNA オリガミ法によって, 自由な 2 次元ナノ構造体 の設計と作製が可能となり，機能化などの面からも活 発に研究開発が行われている2),3). また 1 分子観察の 観点から分子の振る舞いを直接捉えることができるな らば，生命現象を理解するらえで多くの情報を得るこ とが可能である. 高速原子間力顕微鏡（AFM）の登 場により，分子を捉える空間分解能と動画として解析 するためのビデオレートに近い実時間測定が可能と なってきた ${ }^{4)}$ 、本総説では，筆者らが開発したDNA オリガミ構造体と高速 AFM による新規な 1 分子観察 法とその応用について解説する.

DNA オリガミは, $100 \mathrm{~nm}$ 程度のデザイン可能な 2 次元 DNA 構造体で, その構築方法は2006 年にカリ フォルニア工科大学の Rothemund によって開発され た ${ }^{2)}$. この方法では，長鎖の 1 本鎖 DNA（M13mp18,
7,249 塩基）と，構造にあわせて配列設計した相補鎖 DNA（多くは32 量体でステープル DNA と呼ばれる） を混合し， $85^{\circ} \mathrm{C}$ から室温まで 1 時間程度で徐冷（ア ニーリング）することで自己集合によって構造体がで きあがる(図 1)。その形成過程でそれぞれのステー プル DNA はまず長鎖の 1 本鎖 DNA の指定された配 列と相補的に結合し，その後 2 次元構造に折りたたむ と考学られる。その構造は AFM で測定でき, 注設 計どおりの構造体が形成できる。 また，形成された DNAオリガミ構造体のそれぞれの位置には異なるス テープル DNA が用いられているため, 2 次元平面上 の任意の位置に 1 本鎖 DNA やへアピン DNA を配置 することが可能である。 ステープル DNA に機能を持 つ分子や粒子を結合して構造体を形成させれば，それ らを構造体上に自由に配置することができる ${ }^{3)}$ 。この ことから，DNAオリガミによって形成された 2 次元 構造は単なる形だけではなく，その構造のすべての位 置にDNA 配列の情報（アドレス）を持っている. こ の点が DNA オリガミの特筆すべき性質であり, 従来 にはなかった $100 \mathrm{~nm}$ 程度のスケールで精密な自己集 合体が構築でき, 自由な構造のデザインと分子の配置 ができる点で大きなブレークスルーとなった ${ }^{1)}$.

\footnotetext{
Single-molecule Analysis Using DNA Origami Nanostructures

Masayuki ENDO ${ }^{1,3}$ and Hiroshi SUGIYAMA ${ }^{1,2,3}$

${ }^{1}$ Institute for Integrated Cell-Material Sciences (WPI-iCeMS), Kyoto University

${ }^{2}$ Graduate School of Science, Kyoto University

${ }^{3}$ CREST, JST
}

※図 1-図 4 は, 電子ジャーナル (https://www.jstage.jst.go.jp/browse/biophys/-char/ja/) ではカラー版を掲載しています. 
(a)
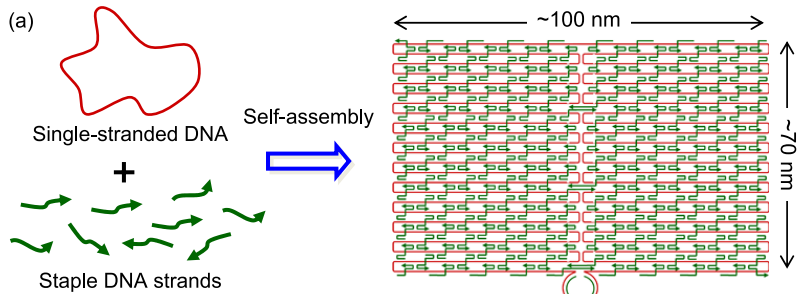

(b)

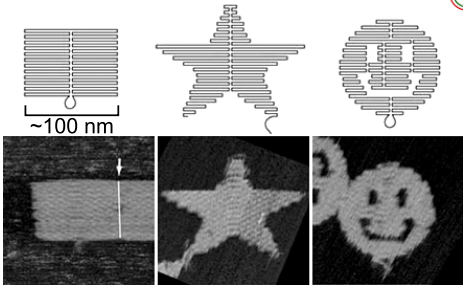

図 1

DNA オリガミの構築方法. （a）長鎖の 1 本鎖 DNA と配列設計し た短い相補鎖 DNA をアニーリングし自己集合させると設計した 形のナノ構造体ができあがる.（b）DNAオリガミ構造体とその AFM イメージ (文献 2 より改変).

筆者らは, DNAオリガミ法で作製したDNAナノ 構造体に酵素やDNA などの生体分子を相互作用させ ることで, 反応のコントロールとその振る舞いを直接 観察する方法を確立した。 DNAによって直接 1 分子 を観察する空間を構築することで，観察上の利便性に 加え, 分子に対して様々な制御や操作も可能となる.

2. 酵素反応の 1 分子観察への応用

筆者らはフレーム状の 2 次元 DNA 構造体を作製し, その内部に 2 本鎖 DNA を張ることで, DNA メチル化 酵素の挙動を直接観察でき，DNA 鎖の張力が酵素反 応に影響することを実験的に示した（図 2 $)^{5}$. DNA 修 飾酵素の多くは特異的な位置で 2 本鎖 DNA を折り曲 ゲ，反応を進行させることが複合体の構造解析から示 唆されている。 このため，2 本鎖 DNA を折り曲げら れる状態と折り曲がらない状態を人工的に作製できれ ば，構造上から酵素反応の制御を行える。これを実験 的に確かめるため，長さの異なる 2 本鎖 DNA を固定 するための空間 $(40 \times 40 \mathrm{~nm})$ を有する 2 次元構造体 「DNA フレーム」構造を設計し，その中に空間と同じ 長さの $64 \mathrm{bp}$ （塩基対）と緩んだ状態の 74 bp の 2 本鎖 DNA を導入した（図 2b)。導入したDNA には，DNA 鎖にEcoRI メチル基転移酵素（M.EcoRI）に特異的な配 列が導入してある. M.EcoRI は DNA 鎖を約 $60^{\circ}$ 折り 曲げることでメチル化反応を行う。M.EcoRIの DNA 鎖への結合では 64 塩基対と 74 bp の 2 本鎖 DNA とも に結合し，そのDNA 鎖上での酵素の挙動を高速 AFM によって捉えた（図 2c)。それ皆れの 2 本鎖 DNAへ (a)

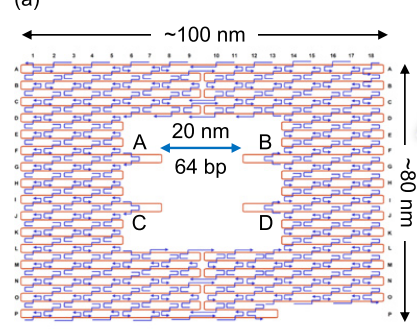

(b) $\quad 64$ mer dsDNA
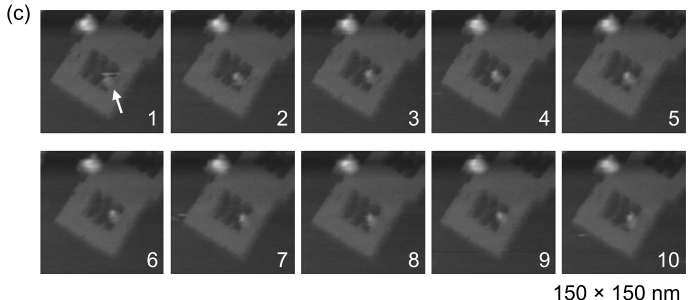

図 2

DNA ナノ構造内での EcoRI メチル転移酵素の反応性の制御.（a） DNA フレーム構造. (b) DNA フレーム構造への 2 本の異なる 2 本鎖 DNA の導入. (c) M.EcoRI の DNA 鎖への結合とスライディン グの高速 AFM による直接観察. 1 イメージ / 秒で測定.

のメチル化反応の効率は M.EcoRI で反応後, EcoRI で 切断し，メチル化されて切断されなかった 2 本鎖 DNA配列をリアルタイムPCR で定量した。 その結果, メチル化されたDNA 鎖の初期濃度から，74bp の DNA が EcoRI の切断を受けにくく, AFM で観察され た切断の結果との一致が見られた。 このことは，緩く 張った 74 bp の DNA ではメチル化反応が， 64 bp の配 列に対してはるかに起こりやすいことを示している.

この方法を使い, 8-oxoguanine glycosylase（hOgg1) と pyrimidine dimer glycosylase（PDG）を用いてこれら の DNA 修復酵素の反応が DNA の張力に対して影響 を受けるか検討した ${ }^{6}$ 。 こ これらの DNA 修復酵素は，2 本鎖 DNAを 60-70折り曲げ，損傷塩基を除去する. このため，DNA フレーム内に反応基質を中心に持つ $64 \mathrm{bp}$ と緩んだ $74 \mathrm{bp}$ の 2 本鎖 DNA を導入し，酵素に よる DNA 鎖切断と中間体と酵素との還元による結合 によって，その反応性の違いを見た。 反応の直接観察 をAFMによって行った結果，緩みの大きい 74 bp の DNA 鎖がどちらの反応とも効率が高かった。 また， 高速 AFM による酵素 1 分子の動的挙動をDNA フレー ム内で観察し, 酵素の結合, スライディング, 切断, 解離が直接観測された。つまり，酵素反応の全過程と それに伴ら酵素 1 分子の挙動をそのままの状態で高速 AFM によって捉えることができた.

筆者らは，DNAオリガミ構造体を観察基盤にして RNA ポリメラーゼと転写の 1 分子観察を検討した ${ }^{7)}$. 転写反応は生命現象の根幹であり，その分子レベルで 
の動的な観察が必要である、プロモータ一領域を含む 鋳型 2 本鎖 DNA を導入したDNA ナノ構造体を作製 し，精製後，導入した 2 本鎖 DNA の動きを確かめた. このDNAナノ構造体にT7 RNA ポリラーゼ (RNAP) を加えると， RNAPが鋳型 DNA 上をスライディング する様子が観察され，その運動を解析した。ささら文 クレオシド 3 リン酸を加光, 高速 AFMによって転写 反応を観察すると，鋳型 DNA 上をRNAP が一方向へ 動き，それに伴って合成された RNA が直接観察され た.この観察系では, RNAP の鋳型 DNAへの結合, スライディング，プロモーターへの結合，RNA 合成， RNAP の鋳型 DNA からの解離といった転写に伴う一 連の RNAP の挙動の可視化が可能である.

これらの結果は，反応機構をもとに，基質となる 2 本鎖 DNA を様々な形でDNAオリガミ構造体へ導入 することで多種多様の観察を行光, 酵素 1 分子の挙動 と反応を実時間に近い状態で直接観測できることを示 している.

\section{DNA 構造変化の 1 分子観察への応用}

DNA フレーム構造体を用いて，グアニン４重鎖構造 の動的な形成と解離を検出する系の構築とその 1 分子 観察を行った ${ }^{8)}$ 。このためにグアニン 4 重鎖構造の形成 によってDNAフレーム構造内に導入した 2 本鎖 DNA の構造変化を誘導し，その動きを高速 AFMによって 観察した. 分割した $[3+1]$ グアニン4重鎖の配列を中 心にそれぞれ含む 2 本の 2 本鎖 DNA を中空な DNA ナノ構造内に固定した（図 3a). 自己集合後にその構 造を AFM で観測すると，2 本鎖 DNA が並んだ構造が

(a)

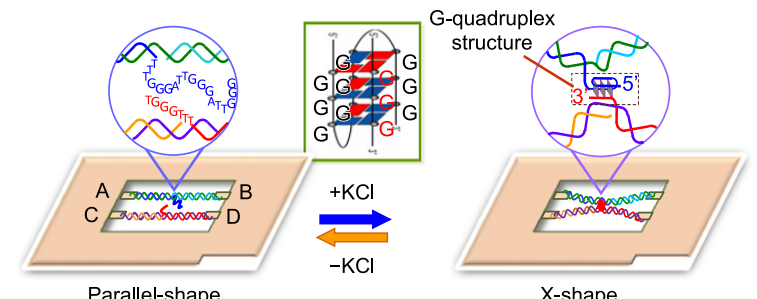

(b)

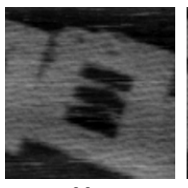

$30 \mathrm{~s}$

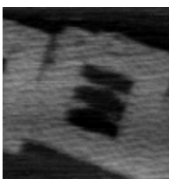

$35 \mathrm{~s}$

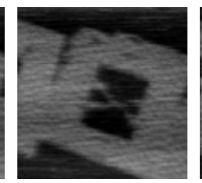

$40 \mathrm{~s}$

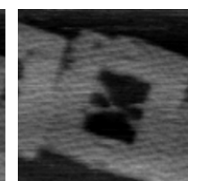

$45 \mathrm{~s}$

図 3

グアニン 4 重鎖構造の動的な形成と解離の 1 分子観察. (a) DNA フレーム構造内の 2 本の 2 本鎖 DNA の中心にグアニン 4 重鎖構 造を形成する配列を導入し，形成されれば 2 本鎖 DNA はX型の 構造をとる.（b）グアニン 4 重鎖構造形成の高速 AFM イメージ.
観察された。この構造体にカリウムイオンを添加する と 2 本鎖 DNA が中心で結合したX型のナノ構造が観 察された. 次に，グアニン 4 重鎖構造の形成をカリウ ムイオン存在下で高速 AFMによって実時間で観察し た。その結果，カリウムイオンを含む観察用の溶液中 で，AFM 走査中にX 型構造を形成するものが観察さ れた（図 3b)。また，グアニン 4 重鎖をカリウムイオ ン非存在下で高速 AFM で観察すると，走査中にX型 の形状から解離した 2 本鎖 DNA に変化する様子が観 察された。このことから，DNAナノ構造体を用いて， 2 本鎖 DNA の構造変化からグアニン 4 重鎖の形成と 解離を動的に 1 分子観測できる系の構築に成功した.

次に，2 本鎖 DNA の解離と形成を 1 分子観察する 系を構築した ${ }^{9)}$. 観察する DNA 鎖には光応答性のア ゾベンゼンが導入してあり，UV光と可視光の照射に よって，2 本鎖の解離と形成をそれぞれ制御できる. この光応答性 DNAを 2 本の 2 本鎖 DNA 結合し, DNA フレームに導入した. 光照射前, 光応答性 DNA は 2 本鎖を形成し，DNA フレーム内でX型の構造を 形成するが, UV 光照射を行らと光応答性 DNA から なる 2 本鎖は解離し， DNA フレーム内に 2 本鎖 DNA が並んだ構造が観察された，さらに，可視光を照射す ると再び 2 本鎖の形成が行われ，X型の構造が観察さ れた。 これらの可逆的な 2 本鎖の解離と形成を高速 AFM 上で光照射を行いながら 1 分子観察すると, 2 本鎖の解離と形成のスイッチングが UV 光と可視光の 照射に応じて連続的に観察された。

DNA フレーム構造体を 1 分子観察系に利用するこ とで DNA 構造の形成や解離を操作でき，その動的な 変化を実時間観察することが可能となった。

4. DNA 分子機械の移動システムへの応用

DNA はその配列特異的な分子集合によって，分子 を動的に操作することが可能であり，DNAによって 構成される分子機械は，その運動をDNA 鎖の結合と 解離でプログラム的に操作できる ${ }^{10)}$ 。筆者らは, DNAを用いた移動可能な分子機械（DNA モーター） をDNAオリガミ上に作製したトラック（経路）を使っ て移動させ，高速 AFMによってその運動を可視化， 解析した ${ }^{11)}$. DNAオリガミ上に 17 本の 1 本鎖 DNA を配置したトラック（約 $100 \mathrm{~nm}$ ）を作製し，DNA モー タ一鎖と呼ぶ相補鎖の 1 本鎖 DNA を加えて酵素反応 させることで，1 方向に連続してモーター鎖を運動さ せることを検討した（図 4a). 図4bに示すように， DNA オリガミに配置した 1 本鎖 DNA とモータ一鎖 
(a)

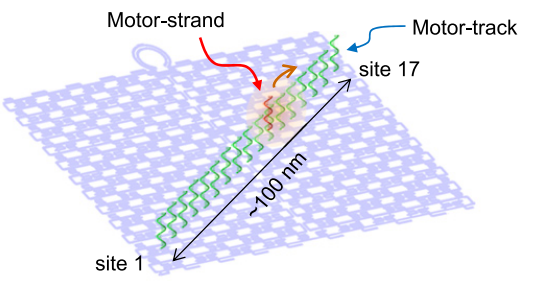

(b)
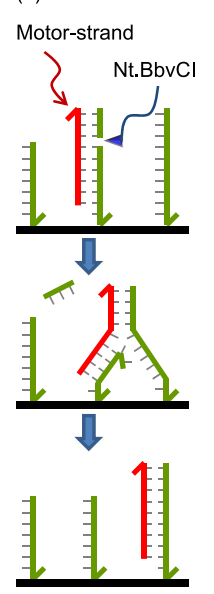

(c)
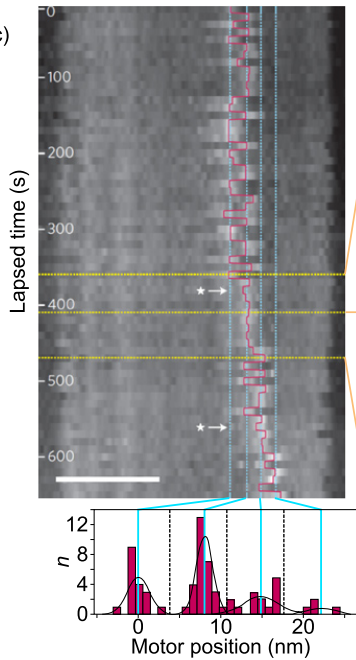
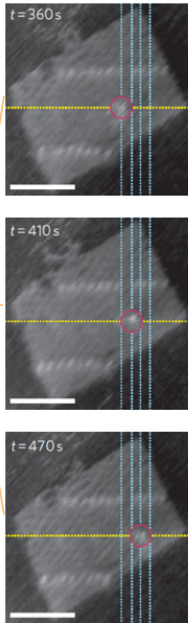

図 4

DNA 運搬システムと DNA モーター 1 分子の運動. (a) DNA 構造 体上に導入した 1 本鎖 DNA のトラック（緑色）と DNA モーター 鎖 (赤色). 酵素反応によってモーター鎖が移動する.（b）DNA モーターの酵素反応による分岐移動の原理. (c) 高速 AFM による モーター鎖の移動の 1 分子観察とその運動の解析.

が 2 本鎖形成し，切断酵素 Nt.BbvCI がトラックの DNA 鎖を切断するとそのDNA 鎖が短くなるので, モーター鎖は隣接する DNA 鎖に移動する（分岐移 動)。トラック上には同じ配列の 1 本鎖 DNA が 1 列 に等間隔で配置してあるため, DNA 鎖の切断と分岐 移動が自律的に進行する。トラックの末端にモーター 鎖を導入し，酵素反応に伴うモータ一鎖の位置を測定 すると，時間経過に伴って，モータ一鎖は 1 方向に移 動することがわかった，さらに，モータ一鎖がトラッ ク上を移動する様子を高速 AFM によって実時間で観 察した。この結果, AFMの走査中にDNA モーターが 運動している様子が直接観察でき，その運動を 1 分子 解析するとDNA モーターの分岐移動の様子とトラッ ク上の 1 本鎖 DNAを介して段階的に移動していくこ とが明らかとなった（図 4c）。

さらに，ナノスケール下で分子の移動を精密に制御 するため, DNA モーターを使ってDNAオリガミ上 に構築した複雑な経路を制御して動かすことを検討し た ${ }^{12)}$. DNAオリガミ上に3 所分岐した経路を作製 し, 分岐点の両側にゲートを設けて, DNA モーター の進行方向の制御を行った。ゲートはあらかじめブ ロック鎖で閉じており，鎖交換反応で取り去ると

DNA モーターが進行できるよらになる。酵素反応を 行い, DNA モーターの位置を AFM による解析と蛍光 消光実験で検討した結果，ゲートの開いた方向に DNA モーターは進み，4つの指定された終着点に精 密に移動させることがでさた。 このよらに，複雑に分 岐した経路を DNA 構造体上に作製し，分子の進行方 向のナノスケールでの制御を可能とする分子技術の開 発に成功した。

また，最近，DNAオリガミ上にトラックを構築し， 連続的な DNA 分子機械の運動を制御でき操作する研 究が報告された ${ }^{13)}$ 14).DNAオリガミを使らことで分 子機械の挙動や運動を行える経路がプログラム可能で あるため, ナノスケールでの複雑な分子機械の運動の 制御と操作や分子の運搬が実現できる.

\section{3 次元 DNA 構造体の構造変化の直接観察}

2 本鎖 DNA は周期的なジオメトリ一を持つため, 2 本鎖 DNA 間の立体配置を工夫すれば，2 次元構造か ら 3 次元構造へ拡張することも可能である ${ }^{1)}$. 中空な 柱状構造（プリズム構造）を形成させ，高速 AFM に よって走査を続けることで, 形成されたプリズム構造 を開環でき，その過程を実時間で観察できる ${ }^{15)}$ 。この ことは, DNAナノ構造体の立体構造の変換が AFM に よる物理的な操作で可能であることを示している。 た，筆者らは 3 次元構造の変換の操作を外部から導入 したDNA 鎖による鎖交換反応を用いて行い，閉じた チューブ構造から開環することで, 内部に導入した鋳 型 DNA から転写を開始できる構造変換を用いた分子 スイッチを作製した ${ }^{16)}$. これらの構造変換技術を基盤 として，ナノ空間への分子の閉じ込めやその放出を利 用した機能性材料への展開も可能である.

6. おわりに

筆者らは，DNAオリガミ法で作製したDNAナノ構 造体に酵素やDNAなどの生体分子を相互作用させるこ とで，反応のコントロールとその振る舞いを直接観察 する方法を確立した，また，DNAによって直接 1 分子 を観察する空間を構築することで，分子に対して様々 な制御や操作を行えることを示した，これらは，設計さ れたナノ空間で生体分子の挙動と反応を動的にから直 接観察できるナノスケールの 1 分子解析システムとし て広く応用可能である. 自在にナノスケールの構造体 を作製できるDNAオリガミ法は，様々な 1 分子観察系 を構築するらえで有用な手法を提供するものと考光る. 
文 献

1) Endo, M., Sugiyama, H. (2009) Chem. Bio. Chem. 10, 2420-2443.

2) Rothemund, P. W. K. (2006) Nature 440, 297-302.

3) Rajendran, A. et al. (2012) Angew. Chem. Int. Ed. Engl. 51, 874890.

4) Ando, T. et al. (2001) Proc. Natl. Acad. Sci. USA 98, 12468-12472.

5) Endo, M. et al. (2010) J. Am. Chem. Soc. 132, 1592-1597.

6) Endo, M. et al. (2010) Angew. Chem. Int. Ed. Engl. 49, 94129416.

7) Endo, M. et al. (2012) Angew. Chem. Int. Ed. Engl. 51, 87788782.

8) Sannohe, Y. et al. (2010) J. Am. Chem. Soc. 132, 16311-16313.

9) Endo, M. et al. (2012) Angew. Chem. Int. Ed. Engl. 51, 1051815822.

10） Bath, J., Turberfield, A. J. (2007) Nat. Nanotechnol. 2, 275-284.

11) Wickham, S. F. et al. (2011) Nat. Nanotechnol. 6, 166-169.

12) Wickham, S. F. et al. (2012) Nat. Nanotechnol. 7, 169-173.

13) Gu, H. et al. (2010) Nature 465, 202-205.
14) Lund, K. et al. (2010) Nature 465, 206-210.

15) Endo, M. et al. (2009) J. Am. Chem. Soc. 131, 15570-15571.

16) Endo, M. et al. (2012) J. Am. Chem. Soc. 134, 2852-2855.

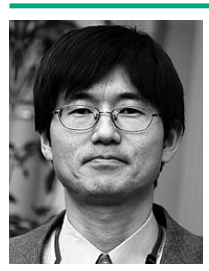

遠藤政幸（えんどうまさゆき）

京都大学准教授

2008 年より物質-細胞統合システム拠点

研究内容:DNA ナノテクノロジー

連絡先: $=606-8501$ 京都市左京区吉田牛ノ宮町

E-mail: endo@kuchem.kyoto-u.ac.jp

遠藤政幸 sugiyama.html

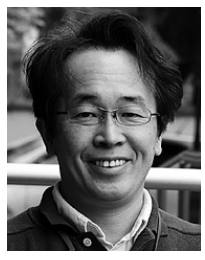

杉山 弘（すぎやま ひろし）

京都大学教授

2003 年より大学院理学研究科

研究内容:ケミカルバイオロジー

連絡先: 7 606-8501 京都市左京区北白川追分町

杉山 弘
E-mail: hs@kuchem.kyoto-u.ac.jp

URL: http://kuchem.kyoto-u.ac.jp/chembio/index. html 